\title{
Long-Term Policy Recommendations for Improving the Efficiency of Heating and Cooling
}

\author{
Krista LAKTUKA ${ }^{1 *}$, Ieva PAKERE ${ }^{2}$, Dace LAUKA ${ }^{3}$, Dagnija BLUMBERGA ${ }^{4}$, \\ Anna VOLKOVA ${ }^{5}$ \\ ${ }^{1-4}$ Institute of Energy Systems and Environment, Riga Technical University, 12-k1 Azenes iela, Riga, \\ LV-1048, Latvia \\ ${ }^{5}$ Tallinn University of Technology, Ehitajate tee 5, 12616, Tallinn, Estonia
}

\begin{abstract}
Targets set by the European Green Deal to increase efficiency, reach towards sustainable development and to reduce greenhouse gas emissions have placed additional focus on necessary improvements in heating and cooling sector. This article aims to determine whether the objectives set at the $\mathrm{EU}$ and on the member state level for achieving climate and environmental goals are being implemented at the regional and local levels. The case of Latvia is considered. A keyword extraction text analysis method is used to identify whether improving the efficiency of heating and cooling is included in regional and local sustainable development strategies. Results are evaluated by using multi-criteria analysis methods TOPSIS and AHP, to determine how much attention in the strategies is paid to direct heating and cooling supply aspects and overall efficiency aspects. Results obtained while assessing the sustainable development strategies of cities and municipalities are compared with the climate index of their heating supply. Considerable differences can be seen in the inclusion of heating and cooling efficiency improvement plans in the strategies at regional and local levels.
\end{abstract}

Keywords - District cooling; district heating; energy efficiency; environmental policy; sustainable development

\section{INTRODUCTION}

Sustainable development cannot be solely based on a voluntary action of society or individual companies. National governments must play an active role in developing national planning documents, creating a clear vision for the future, and building a sustainable policy environment [1]. Governments must not see environmental and energy efficiency issues as separate, detached entities from other policies that initially concentrate on economic, social, juridical, or other everyday issues. States need to look at the wider picture and link the environmental component to any political decision [1]. Application of specific policy instruments at each governing level could enhance the effectiveness of policy instruments used [2]. Primary policy goals and directions should be developed globally or at the EU level, then specified and structured at the national level and finally met at the local level, considering regional specificities [3].

EU programs and regulations on environmental sustainability, protection and pollution abatement are seen as an unprecedented attempt to tackle climate change on a larger scale. For years, governments have been reluctant to address environmental and climate issues, maximizing economic growth and development while seeking to serve the interests of both

* Corresponding author.

E-mail address: krista.laktuka@rtu.lv 
voters and businesses. Historically, decisions taken by governments usually have been formal to reach an agreement with defenders of the environment [2]. However, noticeable changes have taken place in the last decade when the prospects of resource exhaustion and greenhouse gas emissions are perceived as a serious threat to further development [3].

Evaluating the effectiveness of policies and policy instruments in addressing energy efficiency and environmental issues has always been a complex topic [2], [4]. Arithmetic, microdata-based or econometric methods are more commonly used to identify energy savings over time, linked to policy documents issued during the same period, as the savings have appeared [5]. Again, it is difficult to accurately calculate the energy savings that would have occurred independently of policy documents and instruments and the savings that would have resulted from direct policy implications [6], [7]. The counterfactual simulation approach is one way of linking long-term energy savings to policy change. The advantage of the method is the possibility to adapt its use to different geographical conditions, and for the calculations, different data sets can be used, as long as data for a more extended period are available [6].

Bottom-up and top-down methods are also used to calculate energy savings. These methods can be linked to a specific policy instrument called 'policy savings' or energy efficiency improvement programs called 'autonomous energy savings'. The top-down method is based on energy efficiency indicators calculated using statistical data collected by national states. The top-down method can be combined with the econometric method. The choice between bottom-up and top-down methods is based on the available data quality [8], [9].

There are different ways to evaluate local development strategies and plans; a set of tools and criteria developed specifically for this purpose can be used [10], designed to reduce the consumption of resources, improve strategic planning and help to shape improvement forecasts for the future. The toolkit consists of: policy making; best practices and technologies; changing behaviour; main technical data and tools; assessment of resource efficiency strategies and plans [10].

The SWOT method is used in the analysis of long-term planning documents at the regional and local level, identifying strengths, weaknesses, opportunities and threats [11]. The advantage of this method is the possibility to form a discussion around the strategical planning and to choose the best suitable scenario from different possible solutions. Soft systems methodology can also be used to evaluate energy efficiency improvement actions [12] within which a series of sequential actions or research steps, such as problem definition; conceptual modelling; comparison of the model with real situations; formulation of the desired result can be performed.

The use of multi-criteria analysis methods in the process of developing and analysing sustainable development strategies and plans is a commonly used approach [11], [13], [14]. Multi-criteria analysis makes it possible to select specific evaluation criteria and prioritize them, which is particularly valuable in cases where a larger number of aspects are about to be compared [15]. For this reason, multi-criteria analysis was chosen, as it allows comparing sustainable development strategies at both regional and local levels, using the same set of criteria or even making some adjustments, if needed.

In public administration, great emphasis is put on the regulation of development processes through various legislative and regulatory documents, including sustainable development strategies. Theoretically, to achieve climate and environmental goals, these goals must be embedded in documents that provide for the advancement of policy instruments and their implementation. It is necessary to identify whether these objectives are included in sustainable or long-term development plans to predict whether efficiency improvements in heating and cooling could be expected. The technique used would make it possible to identify in due time the possible shortcomings of sustainable development plans at regional and local 
levels, that later could lead to a failure at meeting climate and environmental goals set at the EU level. The obtained data on sustainable development strategies can be combined with the efficiency indicators of heating and cooling systems, thus identifying whether it is necessary to introduce adjustments in development plans and the existing management mechanism in case of poor indicators. Long-term sustainable development planning documents are not used as a planning tool only at Latvian or EU levels; thus, the methodology used can be considered applicable not only for the evaluation of EU Member State strategies, but also at the international level [16]. The research aims to identify if the targets and objectives of National Energy and Climate Plan that are set for the heating and cooling sector have been included in regional planning documents. In addition, the authors analyse if the ambitious targets previously set in the planning documents have resulted in increase of energy efficiency and decarbonization of particular district heating systems.

\section{METHODOLOGY}

Methods for linking policies and policy instruments with energy efficiency and climate change are based mainly on data analysis, focusing less on the quality of the policy documents and the ability to define objectives to be achieved. Policy documents and strategic development plans can be analysed to achieve future targets. Policy documents should serve as guidelines or detailed action plans, but what happens if this 'instruction' is implemented inaccurately and conflicts with other equivalent policy documents or lacks strategic thinking? In this case, the desired result cannot be achieved, regardless of the number of policy documents and sustainable plans approved.

\subsection{Regional development plan analysis}

According to existing regulations [17], all planning regions (PR) must develop sustainable development strategies. There are 5 PR in Latvia: Kurzeme PR, Latgale PR, Riga PR, Vidzeme PR, Zemgale PR. Sustainable development strategies have been developed in these regions [17]-[22].

\subsubsection{Keyword Extraction Text Analysis Method}

Keyword extraction text analysis method was used to identify whether the objectives and targets defined in the EU and Latvian legislation or long-term planning documents [1], [3], [23], [24] are implemented in regional and local sustainable development strategies. Therefore, the key priorities and policy measures for improving the efficiency of heating and cooling were used as keywords for analysing the strategies. Eleven keywords were selected (Table 1), only the root of the word was used for the analysis of the documents in order to increase the possibility of finding all measures related to efficiency improvements. Direct heat and cold supply aspects (direct aspects) and overall efficiency aspects (indirect aspects) were identified as the most commonly used keywords connected with necessary improvements in heating and cooling. Direct aspects were chosen as most precisely connected and with the highest possible outright influence to the heating and cooling sector: increasing energy efficiency; reducing GHG emissions by switching to renewable energy sources; reducing heat losses during heat production and transmission process; connection of new consumers to the central heating and cooling networks. Indirect aspects are supplementary related to the heating and cooling sector or its regulation. Nonetheless, improvements in these areas could reduce the number of resources used for heat production, for example, changes in the tax system (tax greening); informing the public about the need to improve energy 
efficiency; regional and local shifting towards sustainable development. Sustainable use of resources could have a positive impact on the overall national sustainable development process and bring additional energy savings that could eventually refer to the heating and cooling sector positively.

\section{TABLE 1. KeYWORdS USED to IDENTIFy POLICY MEASURES THAT DIRECTLY OR INDIRECTLY INFLUENCE IMPROVEMENTS IN THE HEATING AND COOLING SECTOR}

\begin{tabular}{ll}
\hline $\begin{array}{l}\text { Direct heating and cooling supply aspects (direct } \\
\text { aspects) }\end{array}$ & Overall efficiency aspects (indirect aspects) \\
\hline $\begin{array}{l}\text { Heat supply and connection of new consumers to the } \\
\text { central heat supply system; }\end{array}$ & Insulation of buildings \\
Cooling & Tax greening, discounts, reductions \\
Renewable energy resources (RES) & Sustainable development \\
Energy efficiency & Energy poverty \\
Heat losses & $\begin{array}{l}\text { Informing the public about the implementation of energy } \\
\text { efficiency measures, use of RES, resource-saving }\end{array}$ \\
& Sustainable use of biomass, reforestation, planting \\
\hline
\end{tabular}

The identified keywords were used to analyse sustainable development strategies to 2030 of 5 PRs of Latvia. The obtained results were summarized and ranked in the table. Each measure mentioned under each of the eleven aspects was assigned a value $0,0.5,1,3$, or 5 (Table 2).

\section{Table 2. Values Assigned for Policy Measures in Sustainable DeVelopment STRATEGY ANALYSIS}

\begin{tabular}{ll}
\hline Value & Value allocation \\
\hline 0 points & $\begin{array}{l}\text { keyword is not mentioned in the planning document or is mentioned in a completely different } \\
\text { context }\end{array}$ \\
0.5 points & $\begin{array}{l}\text { the mentioned measure is repeated under several keywords (for example, sustainable use of energy } \\
\text { resources in heat supply; use of RES in heat supply) }\end{array}$ \\
1 point & $\begin{array}{l}\text { the measure to be taken in the planning document is mentioned in general terms, statement of fact } \\
\text { without a specific direction (for example, an increase of energy efficiency, insulation of buildings, }\end{array}$ \\
& $\begin{array}{l}\text { RES, housing stock is obsolete) } \\
\text { the measure to be performed in the planning document is mentioned in the context of a specific }\end{array}$ \\
& $\begin{array}{l}\text { sector or a set of tasks to be performed (renovation and insulation of residential buildings, } \\
\text { renovation of heating supply networks; development of the forestry sector) }\end{array}$ \\
& $\begin{array}{l}\text { the measure to be implemented in the planning document has a specific goal/object and is directly } \\
\text { related to sustainable development and energy efficiency, there is a high probability that the } \\
\text { measure will be implemented }\end{array}$ \\
\hline
\end{tabular}

\subsubsection{Multi-Criteria Analysis}

The obtained values were analysed with the multicriteria analysis method Technique for Order Preference by Similarity to Ideal Solution (TOPSIS) and Analytic Hierarchy Process (AHP) methods. The multicriteria analysis TOPSIS is a frequently used method to evaluate environmental strategies for sustainable development [9], [15]. The main purpose of TOPSIS is to allow comparison and choice between several alternatives.

TOPSIS and AHP methods were used to analyse direct and indirect aspects (Table 1). It is evaluated how much attention has been paid to these aspects by all 5 Latvian PR in their 
sustainable development strategies to 2030. The calculation was performed according to the steps and formulas presented by previous studies [8]-[10], [25], [26].

Compiling of the decision-making matrix identified that no information on aspects of 'Cooling', 'Heat loss' and 'Energy poverty' has been found in development plans, so these criteria are excluded from further calculations. Normalisation of values was performed, and the normalised decision matrix was compiled.

When the normalized evaluation of all alternatives according to the criteria is obtained, it is necessary to determine the individual weight of each criterion. Weights are determined by using AHP method described in [10] and summarized in Fig. 1.

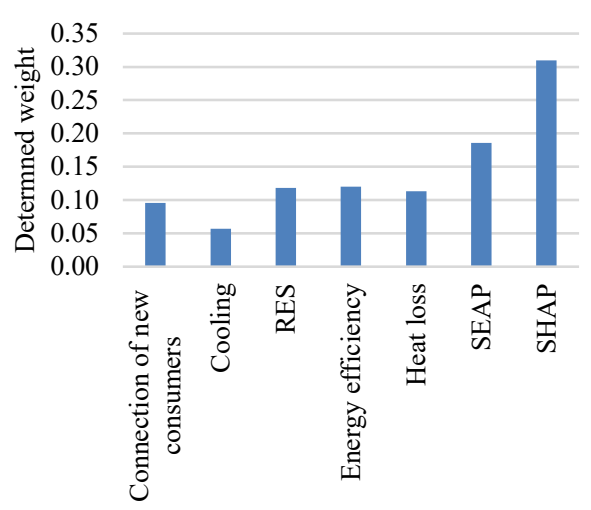

a)

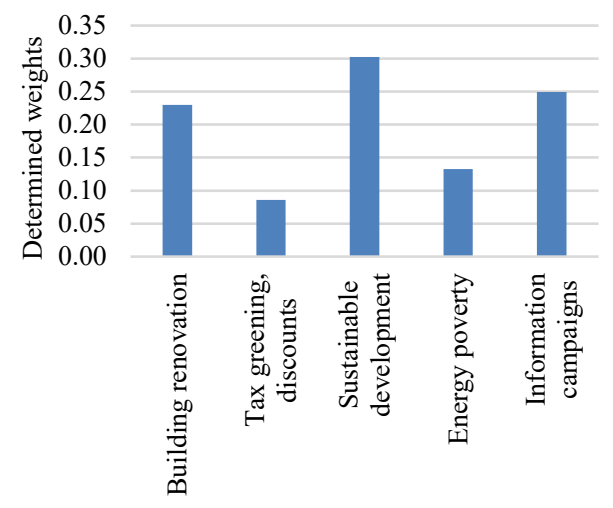

b)

Fig. 1. Determined weights of direct aspects for a) local planning documents and b) indirect aspects for all planning documents.

In order to determine the impact of the weights of the criteria set by the AHP on the evaluation of criterion, a re-evaluation of criteria is performed, assigning equal values to all alternatives.

\subsection{Local Development Plan Analysis}

The existing regulation stipulates that local governments shall develop sustainable development strategies and development programs. The law requires that when developing sustainable development strategies, local governments must include a long-term development vision, strategic goals, long-term priorities, territorial specialization as well as a spatial development perspective [27].

In total, ten largest cities or municipalities that represent all PR have been chosen. As the cities to be analysed were selected to cover all PR, an additional criterion was added - in addition to the sustainable development strategies, the city or municipality should have had issued a Sustainable Energy Action Plan (SEAP) or a Sustainable Heating Action Strategy (SHAP) (or both) [16], [20]-[28]. It was assumed that this factor could indicate a more decisive implementation of climate and environmental objectives. The following cities of national importance or municipalities were selected - Broceni, Cesis, Daugavpils, Gulbene, Jekabpils, Jelgava, Liepaja, Riga, Salaspils, Ventspils. Sustainable development strategies of the selected cities and municipalities were analysed according to the same principle as the sustainable development strategies of PR. The same keywords were used (Table 1). The 
obtained results were summarized and ranked (Table 2). Additional ten points were assigned if a SEAP or a SHAP had been developed for the city or municipality.

Again, TOPSIS and AHP methods were used to analyse five direct and six indirect aspects in the sustainable development strategies of each of the ten selected cities or municipalities. After compiling the decision-making matrix on indirect aspects, it was identified that no information on 'Energy poverty' has been found in development plans, so this criterion was excluded from further calculations.

AHP method is used to determine the individual weight of each criterion for direct aspects. Separate evaluation is carried out because direct aspects of cities and municipalities include more evaluation criteria than PR. The evaluation of indirect criteria for cities and municipalities by the AHP method was not repeated, but the same criteria weights, as for sustainable strategies of PR were used for TOPSIS calculations, as they were identical.

Finally, the results obtained with TOPSIS and AHP methods on the sustainable development strategies of cities and municipalities were compared with each city's climate index of heat supply system. The climate index is created by using seven different criteria in the calculations and evaluating the efficiency of a particular heat supply system and its sustainability and impact on the climate. The methodology of the climate index determination is presented in previous studies of the authors [28]. Main criteria in the climate index is share of RES, share of RES cogeneration, specific $\mathrm{CO}_{2}$ emissions, environmental costs, specific heat losses, primary energy factor and share of heat delivered by industrial enterprises.

\section{RESUlts}

Summarizing the results of PR sustainable development strategies (Table 3), it can be seen that the highest indicator was shown by Vidzeme PR with 87 points, the second highest was shown by Zemgale PR with 61 points, Kurzeme PR took the third place with 43 points. The fourth highest result was presented by Riga PR - 31 points, and the lowest result was shown by Latgale PR - only 6.5 points. Taking a closer look at the distribution of points by direct and indirect aspects, it can be seen that Vidzeme PR has the highest number of points in both groups of aspects, just as Zemgale PR has obtained the second-highest number of points in the list of both aspects. Interestingly, all regions scored higher in the group of indirect aspects. Most mentioned measures related to sustainable use of resources, directly related to forest management and use of wood. Direct aspects in sustainable development strategies are discussed relatively infrequently. The most often mentioned direct aspect is 'RES'. Two direct aspects are not mentioned at all: 'Cooling' and 'Heat loss'. An indirect aspect that has not been mentioned is 'Energy poverty'. Values obtained in the evaluation of the sustainable development strategies of the PR (Table 3) were analysed with multi-criteria decision-making analysis method TOPSIS, assigning them criterion weights. Authors have not included in calculation those aspects that are not mentioned in the sustainable development strategies: 'Cooling', 'Heat loss' and 'Energy poverty'.

Fig. 2 shows the obtained results by TOPSIS and AHP analysis methods. Kurzeme PR and Vidzeme PR have paid the biggest attention to the inclusion of direct and indirect aspects in their sustainable development strategies. Vidzeme PR is the closest to the ideal positive result and has reached the maximum number of points in the evaluation of direct aspects (1.00) and has reached the highest score in evaluating indirect aspects (0.88). Kurzeme PR is in the second place in the evaluation of both, direct (0.86) and indirect (0.30) aspects. In evaluating direct aspects, the Riga PR received an assessment of 0.18 points indirect aspects and 0.21 points in indirect aspects. Zemgale PR received 0.04 points in the assessment of direct aspects 
and 0.25 points in indirect aspects. Latgale PR had the lowest score in both direct aspects $(0.01)$ and did not score any points in indirect aspects.

Table 3. Policy Measure Evaluation of Sustainable Development Strategies of PR BY DIRECT AND INDIRECT ASPECTS

\begin{tabular}{llllll}
\hline Aspects & $\begin{array}{l}\text { Kurzeme } \\
\text { PR }\end{array}$ & $\begin{array}{l}\text { Latgale } \\
\text { PR }\end{array}$ & Riga PR & Vidzeme PR & Zemgale PR \\
\hline $\begin{array}{l}\text { Heat supply and connection of } \\
\text { new consumers }\end{array}$ & 0 & 0 & 5 & 3 & 0 \\
\hline Cooling & 0 & 0 & 0 & 0 & 0 \\
\hline RES & 2 & 2 & 1 & 21 & 15 \\
\hline Energy efficiency & 8 & 1 & 3 & 9,5 & 0 \\
\hline Heat loss & 0 & 0 & 0 & 0 & 0 \\
\hline Direct aspects (Total) & 10 & 3 & 9 & 33.5 & 15 \\
\hline Insulation of buildings & 0 & 0 & 0 & 9 & 0 \\
\hline $\begin{array}{l}\text { Tax greening, discounts, } \\
\text { reductions }\end{array}$ & 0 & 0 & 1 & 0 & 0 \\
\hline Sustainable development & 10 & 2.5 & 9.5 & 16 & 4 \\
\hline Energy poverty & 0 & 0 & 0 & 0 & 0 \\
\hline $\begin{array}{l}\text { Informing the public about the } \\
\text { implementation of energy } \\
\text { efficiency measures, use of RES, } \\
\text { resource saving }\end{array}$ & 1 & 0 & 0.5 & 0.5 & 0 \\
\hline $\begin{array}{l}\text { Sustainable use of biomass, } \\
\text { reforestation, planting }\end{array}$ & 22 & 1 & 11 & 28 & 42 \\
\hline Indirect aspects (Total) & 33 & 3.5 & 22 & 53.5 & 46 \\
\hline IN TOTAL: & $\mathbf{4 3}$ & $\mathbf{6 . 5}$ & $\mathbf{3 1}$ & $\mathbf{8 7}$ & $\mathbf{6 1}$ \\
\hline
\end{tabular}

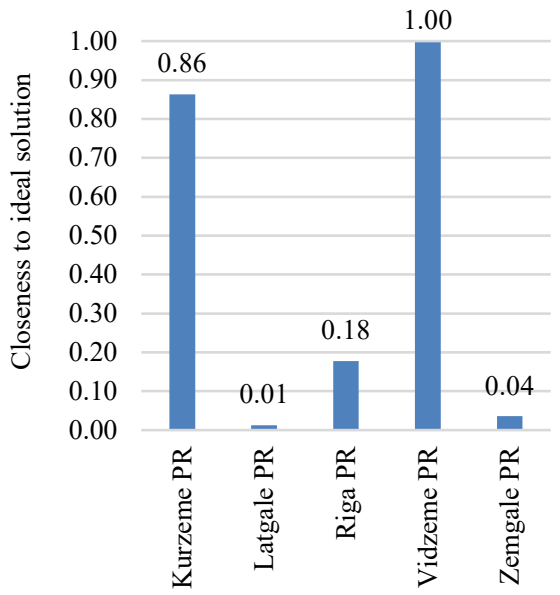

Planning Regions

a)

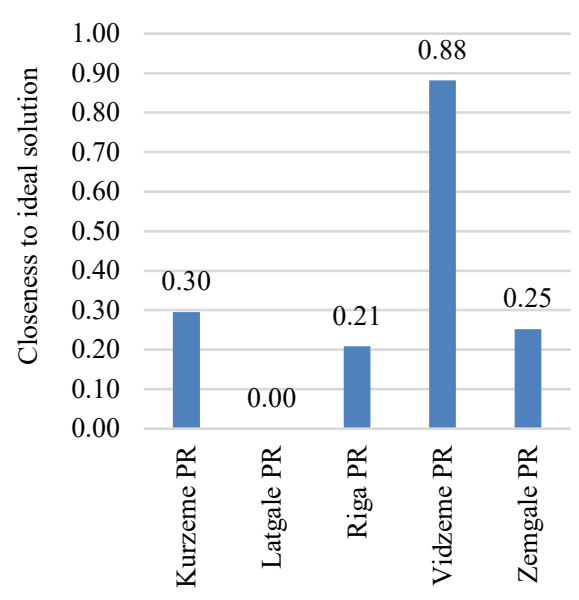

Planning Regions

b)

Fig. 2. TOPSIS and AHP evaluation results of a) direct aspects and b) indirect aspects for planning regions. 
It can be determined that Vidzeme PR takes the goals set at the national level most seriously; targets have been included in its sustainable development strategy. Kurzeme PR has obtained the second-highest result (0.86) to evaluate direct aspects. Although the strategy has not focused directly on heat supply, the need to take energy efficiency measures seriously has been acknowledged. After applying the TOPSIS and AHP methods, we can see that Riga PR has shown a relatively similar result in evaluating both direct and indirect aspects. Zemgale PR has paid little attention to direct aspects, where only 0.04 points have been obtained, but there has been a greater emphasis on forest management and sustainable use of forest resources to obtain the third-highest rating (0.25) among indirect aspects. Latgale PR has obtained the lowest result in evaluating both aspects, which means that the goals set at the national level have not been implemented in the strategy.

\subsection{Sustainable Development in Cities and Municipalities}

Local authorities play a crucial role in the sustainable development of district heating systems. In order to identify the role of local planning documents, an in-depth analysis was carried out according the methodology described above. The results of cities and municipalities are summarized in Table 4.

Table 4. Policy Measure Evaluation of Sustainable Development Strategies of CitIES AND MuniCIPALITIES BY DIRECT AND INDIRECT ASPECTS

\begin{tabular}{|c|c|c|c|c|c|c|c|c|c|c|}
\hline Aspects & 馬 & 造 & 竞 & $\underset{\Xi}{\stackrel{\Xi}{\Xi}}$ & $\frac{0}{\overline{0}}$ & 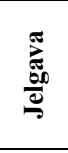 & 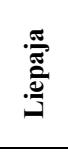 & $\frac{\pi}{200}$ & $\begin{array}{l}\frac{n}{\bar{n}} \\
\frac{\tilde{E}}{\tilde{N}} \\
\tilde{n}\end{array}$ & 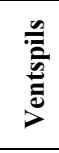 \\
\hline Connection of new consumers & 1 & 28.5 & 32 & 6.5 & 14.5 & 12.5 & 0 & 0.5 & 9.5 & 1 \\
\hline Cooling & 0 & 0 & 0 & 0 & 0 & 0 & 0 & 0.5 & 0 & 0 \\
\hline RES & 3 & 15 & 20 & 6 & 3 & 6 & 0 & 6 & 4 & 0 \\
\hline Energy efficiency & 3 & 10 & 5.5 & 2 & 3.5 & 19 & 1.5 & 1 & 7 & 3.5 \\
\hline Heat loss & 0 & 0 & 0 & 0.5 & 0.5 & 0.5 & 0 & 0 & 0 & 0 \\
\hline SEAP & 0 & 10 & 10 & 10 & 10 & 10 & 10 & 10 & 10 & 0 \\
\hline SHAP & 10 & 10 & 10 & 0 & 0 & 0 & 0 & 10 & 0 & 10 \\
\hline Direct aspects (Total) & 17 & 73.5 & 77.5 & 25 & 31.5 & 48 & 11.5 & 28 & 30.5 & 14.5 \\
\hline Renovation of buildings & 7 & 24 & 30.5 & 18.5 & 1 & 24.5 & 3 & 17 & 10 & 5 \\
\hline Tax greening, discounts, reductions & 0 & 0 & 0 & 0 & 0 & 0 & 0 & 5 & 0 & 1 \\
\hline Sustainable development & 8 & 15.5 & 12 & 21 & 2 & 4.5 & 2 & 4 & 9.5 & 2 \\
\hline Energy poverty & 0 & 0 & 0 & 0 & 0 & 0 & 0 & 0 & 0 & 0 \\
\hline $\begin{array}{l}\text { Informing the public about the } \\
\text { implementation of energy efficiency } \\
\text { measures, use of RES, resource } \\
\text { saving }\end{array}$ & 0 & 0 & 0 & 0 & 0.5 & 0 & 0 & 0 & 0 & 0 \\
\hline $\begin{array}{l}\text { Sustainable use of biomass, } \\
\text { reforestation, planting }\end{array}$ & 16 & 14.5 & 1 & 9.5 & 0 & 0 & 0.5 & 1 & 0 & 0 \\
\hline Indirect aspects (Total) & 31 & 54 & 43.5 & 49 & 3.5 & 29 & 5.5 & 27 & 19.5 & 8 \\
\hline Total: & 48 & 127.5 & 121 & 74 & 35 & 77 & 17 & 55 & 50 & 22.5 \\
\hline
\end{tabular}

Cesis obtained the highest score in the evaluation of direct and indirect aspects with 127.5 points. Daugavpils obtained the second highest result with 121 points, and Jelgava 
obtained the third-highest result with 77 points, of which Gulbene is not far behind with 74 points. Then the cities were ranked in the following order: Riga (55 points), Salaspils (50 points), Broceni (48 points), Jekabpils (35 points), Ventspils (22.5 points) and Liepaja (17 points).

Direct aspects such as 'Heat supply and connection of new consumers to the district heating', 'RES', 'Energy efficiency' are mentioned relatively often. Among the most frequently mentioned indirect aspects are 'Renovation of buildings', 'Sustainable development' and 'Sustainable use of biomass, reforestation, planting'. No strategy mentions the need to address the risks of 'Energy poverty'. Aspects such as 'Cooling', 'Heat loss', 'Informing the public about the implementation of energy efficiency measures, use of RES, resource-saving' are mentioned only in connection with other aspects and received only 0.5 points per city or municipality.

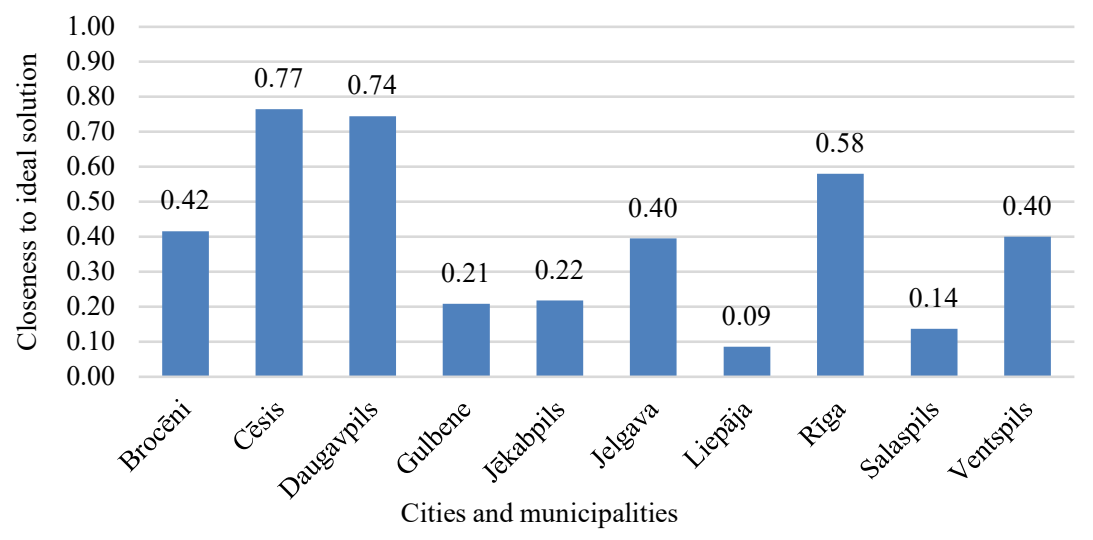

Fig. 3. Direct aspects TOPSIS and AHP evaluation results.

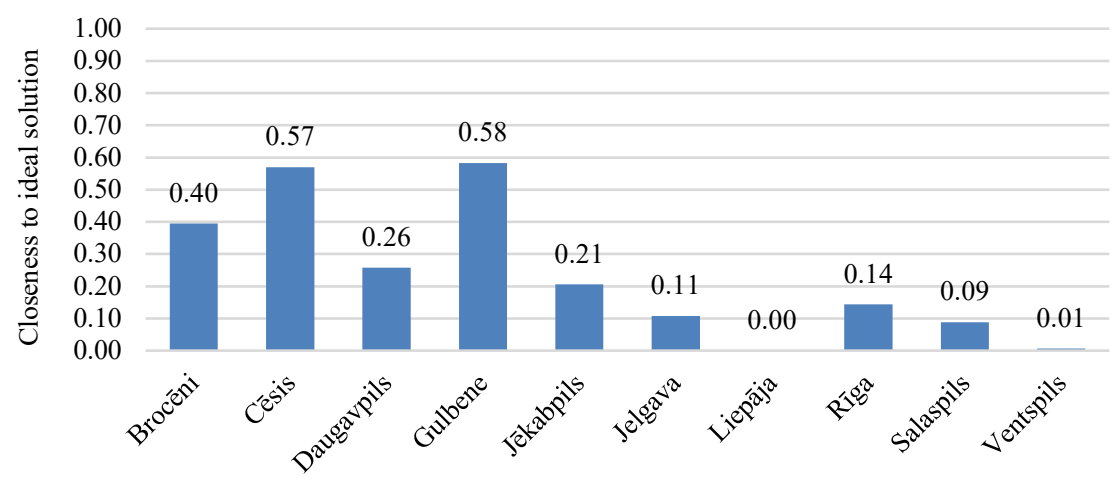

Cities and municipalities

Fig. 4. Indirect aspects TOPSIS and AHP evaluation results.

As the next step, values obtained in the evaluation of the sustainable development strategies of cities and municipalities were analysed with multi-criteria analysis method TOPSIS, assigning them criteria weights with the help of the AHP evaluation method. An aspect not 
mentioned in the sustainable development strategies, 'Energy poverty,' was not included in the calculation. Results obtained are visualized for direct aspects in Fig. 3 and for indirect aspects in Fig. 4.

The following cities achieved the closest score to ideal positive result in the evaluation of direct aspects - Cesis (0.77), Daugavpils (0.74), Riga (0.58). Below the mark 0.5 are 7 cities. From the results, we can assess that Cesis, Daugavpils, and Riga have paid the most attention from all the cities and municipalities to improvements of the heat supply sector and energy efficiency. Relatively few direct aspects are mentioned in the sustainable development strategies of Liepaja and Salaspils. Evaluating the indirect aspects, it can be seen that Gulbene, Cesis, and Broceni have considered the aspects in a generic way. Salaspils, Ventspils, and Liepaja have paid little attention to the inclusion of indirect aspects in their strategies.

The obtained multi-criteria analyses results are very different. Starting with Cesis, Daugavpils, and Riga, which all exceed the 0.58 limit and are closest to the ideal positive option. Within the points from 0.20-0.42, there were five cities - Broceni, Gulbene, Jekabpils, Jelgava, Ventspils, which means they have paid medium attention in planning of improvements in heat supply. Results below 0.2 points were obtained by two cities - Salaspils and Liepaja, which in their sustainable development strategies have focused on other priorities than the development of heat supply, increased energy efficiency, and broader use of RES.

Sustainable development strategies of cities and municipalities were developed in the year 2014-2015 and compared with the average climate index of cities of the period from the year 2017 to 2019 which means that cities have had time to implement them after adopting strategies. Climate index merges different sustainability parameters of particular district heating system. The comparison can be seen in Fig. 5.

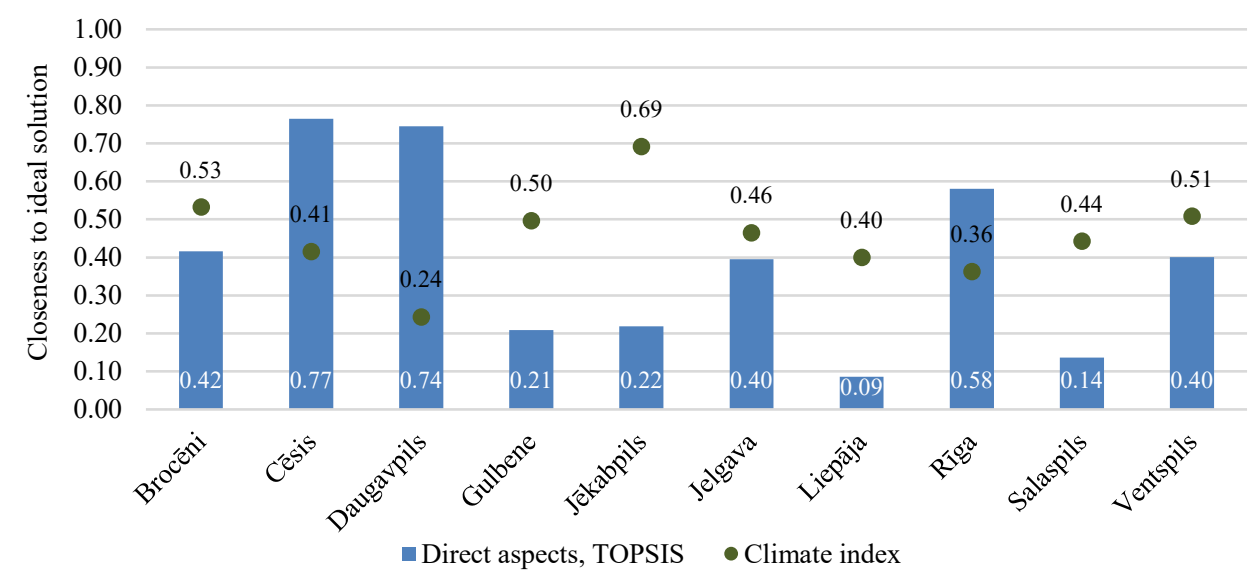

Fig. 5. Climate Index indicators and results of TOPSIS analyses for sustainable development strategies.

Comparing the indicators of these cities with the climate index in Fig. 5, it can be seen that the results differ - in the case of Cesis, which has the highest score for planning document analyses, the climate index indicator is 0.36 points lower, while in Daugavpils, it differs by 0.5 points. The third-highest rating in evaluating the development strategy was obtained by Riga, for which the climate index is also lower by 0.22 points. For several cities, the climate index scores are higher than those obtained in evaluating the sustainable development 
strategies, where they received a lower score. Climate index for Gulbene is by 0.29 points, Jekabils by 0.47 points, Liepaja by 0.31 points, Salaspils by 0.3 points higher than the assessment obtained in evaluating sustainable development strategies. The sustainable development strategy and the climate index assessment obtained for three cities almost coincided - Broceni, difference 0.11 points, Jelgava 0.06 points difference, Ventspils 0.11 points difference.

Differences between climate index indicators and results of sustainable development strategies of cities and municipalities could indicate several things. As the development of sustainable development strategies has been a mandatory task for all 119 Latvian cities and municipalities, many municipalities may have developed strategies because it has been a mandatory measure [27], [29] without trying to align them with actual changes and improvements. In the case of Cesis and Daugavpils, which had the highest TOPSIS and AHP direct aspect evaluation results, differences may have arisen due to insufficient opportunities and funding for the achievement of the goals set in the development strategy. As well sustainable development strategies were developed until 2030. Thus, the cities are still in the middle of the planning period. In Gulbene, Jekabpils and Liepaja, which have a higher climate index than the assessment obtained in the sustainable development strategy, they may not have placed particular emphasis on improvements of the heating sector and energy efficiency in the strategy, as improvements might already be in motion. There is no direct link seen between a high or low score in the sustainable development strategy and the climate index. Although for three cities (Broceni, Jelgava, Ventspils), climate index indicators and obtained results in evaluating direct aspects of sustainable development strategies were relatively close.

The direct aspect of the strategies of cities and municipalities compared with their climate index of heat supply systems revealed another aspect - information that contains sustainable development strategies or the quality of it is not directly related to the performance indicators of a city or municipality. As the sustainable development strategies have been developed for the period until 2030, there is a possibility that not all local governments have had the opportunity to fully implement them in practice. A more accurate assessment of sustainable development strategies with climate index would require data on climate index at the same period when the sustainable development strategies were implemented. In that case, it would be possible to compare the situation in each municipality or city before the enactment of sustainable development strategies and how they have changed over the time. Then it would be possible to assess whether sustainable development strategies have had a practical contribution to the district heating sector's improvements and energy efficiency. To fully assess the impact of sustainable development strategies on the development of the heating sector, an in-depth study of each city should be carried out. It would be necessary to look at the situation that prevailed before adopting the strategy - technologies and their efficiency, heat losses in transmission lines, available resources, the number of inhabitants in the settlement, etc.

\section{Discussion AND CONCLUSION}

The evaluation of sustainable development strategies of PR shows that not all PRs have paid equal attention to heat supply, efficiency, and other related measures. Differences are significant, which shows that objectives set by the state are not implemented to the same degree at the regional level. As a result, there may be problems in meeting requirements set at the EU level, as improvements in the heat supply sector are mainly the responsibility of the regions and local governments. 
The methodology developed for evaluating policy documents and instruments can be used to determine whether the objectives set at the national level are considered and are about to be implemented and addressed at the regional and local level. It can be considered as flexible and easily adaptable to the assessment of various aspects and even sectors by adding or removing other criteria or changing their determined weight.

For further development and achievement of environmental goals, it is necessary to develop a detailed action plan, anticipating both the tasks to be performed and the approximate costs to create a more stable investment climate. The district heating sector is left to the discretion of municipalities, which do not always have the financial and administrative resources to achieve necessary climate and environmental goals. It can be seen in the existing sustainable development strategies, the quality of which varies considerably. Attention and support from the national government must be given to regions and municipalities by providing practical and financial support.

It should be mentioned that, for example, in Estonia the preparation of the development plan for heating management for district heating regions are supported by Estonian government [30]. As a result, around 150 local development plans for heating management are available [31]. The above described analysis algorithm can be applied for this group of plans, too.

In Latvia, the cooling sector is considered to be non-existent. Plans of the development of the cooling sector has received little attention to no attention on the regional and local level.

\section{ACKNOWLEDGEMENT}

This work has been supported by the State Research Program (VPP) project 'Development of heat supply and cooling systems in Latvia' (project No. VPP-EM-EE-2018/1-0002).

\section{REFERENCES}

[1] European Commission. COMMUNICATION FROM THE COMMISSION. The European Green Deal. Brussels: European Commission, 2019. [Online]. Available: https://ec.europa.eu/info/strategy/priorities-2019-2024/europeangreen-deal_en

[2] Carter N. The Politics of the Environment. Ideas, Activism, Policy. Cambridge: Cambridge University Press, 2004.

[3] European Commission. Directive 2012/27/EU of the European Parliament and of the Council of 25 October 2012 on energy efficiency, amending Directives 2009/125/EC and 2010/30/EU and repealing Directives 2004/8/EC and 2006/32/EC Text with EEA relevance. Official Journal of the European Union 2012: L 315/1

[4] Aboltins R., Blumberga D. Key Factors for Successful Implementation of Energy Efficiency Policy Instruments: A Theoretical Study and the Case of Latvia. Environmental and Climate Technologies 2019:23(2):187-206. https://doi.org/10.2478/rtuect-2019-0063

[5] Bohm P. Chapter 10 - Experimental evaluations of policy instruments. Handbook of Environmental Economics 2003:1:437-460. https://doi.org/10.1016/S1574-0099(03)01015-5

[6] Horowitz M. J. Measuring the savings from energy efficiency policies: A step beyond program evaluation. Energy Efficiency 2011:4(1):43-56. https://doi.org/10.1007/s12053-010-9082-6

[7] Filippini M., Hunt L. C. Zorić J. Impact of energy policy instruments on the estimated level of underlying energy efficiency in the EU residential sector. Energy Policy 2014:69:73-81. https://doi.org/10.1016/j.enpol.2014.01.047

[8] Thomas S., et al. How to measure the overall energy savings linked to policies and energy services at the national level? Energy Efficiency 2012:5(1):19-35. https://doi.org/10.1007/s12053-011-9122-x

[9] Boonekamp P. G. M. How much will the energy service directive contribute to the $20 \%$ EU energy savings goal? Energy Efficiency 2011:4(2):258-301. https://doi.org/10.1007/s12053-010-9088-0

[10] Salvia M., et al. Creating a sustainable and resource efficient future: A methodological toolkit for municipalities. Renewable and Sustainable Energy Reviews 2015:50:480-496. https://doi.org/10.1016/j.rser.2015.05.027

[11] Terrados J., Almonacid G., Hontoria L. Regional energy planning through SWOT analysis and strategic planning tools. Impact on renewables development. Renewable and Sustainable Energy Reviews 2007:11(6):1275-1287. https://doi.org/10.1016/j.rser.2005.08.003 
[12] Neves L. P., et al. Structuring an MCDA model using SSM: A case study in energy efficiency. European Journal of Operational Research 2009:199(3):834-845. https://doi.org/10.1016/j.ejor.2009.01.053

[13] Neves D., et al. Designing a municipal sustainable energy strategy using multi-criteria decision analysis. Journal of Cleaner Production 2018:176:251-260. https://doi.org/10.1016/j.jclepro.2017.12.114

[14] Mirakyan A., De Guio R. Integrated energy planning in cities and territories: A review of methods and tools. Renewable and Sustainable Energy Reviews 2013:22:289-297. https://doi.org/10.1016/j.rser.2013.01.033

[15] Balioti V., Tzimopoulos C., Evangelides C. Multi-Criteria Decision Making Using TOPSIS Method Under Fuzzy Environment. Application in Spillway Selection. Proceedings 2018:2(11):637. https://doi.org/10.3390/proceedings2110637

[16] European Commission. Sustainable Development [Online]. [Accessed 04.06.2021]. Available: https://ec.europa.eu/environment/eussd

[17] Cabinet of Ministers. Ministru kabineta noteikumi Nr. 402. Noteikumi par plānošanas reǵionu teritorijas attīstības plānošanas dokumentiem (Cabinet of Ministers Regulation No. 402. Regulations on Territorial Development Planning Documents of Planning Regions). Latvijas Vēstnesis 2013:148. (in Latvian)

[18] Latgale Planning Region. Latgales stratēǵija 2030 (Latgale Strategy 2030). Daugavpils: LPR, 2010. (in Latvian)

[19] Kurzeme Planning Region. Kurzemes plānošanas reǵiona Ilgtspējīgas attīstības stratēǵija (Kurzeme Planning Region Sustainable Development Strategy for 2015-2030). Saldus: KPR, 2015. (in Latvian)

[20] Riga Planning Region. Rīgas Plānošanas Reǵiona Ilgtspējīgas Attīstības Stratēǵija 2014 - 2030 (Sustainable Development Strategy of Riga Planning Region 2014 - 2030). Riga: RPR, 2015. (in Latvian)

[21] Vidzeme Planning Region. Vidzemes Plānošanas Reǵiona Ilgtspējīgas Attīstības Stratēgeija 2030 (Vidzeme Planning Region Sustainable Development Strategy 2030). Cesis: VPR, 2015. (in Latvian)

[22] Zemgale Planning Region. ZPR Ilgtspējīgas attīstības stratēǵija 2015 - 2030 (Sustainable Development Strategy of Zemgale Planning Region 2015-2030). Jelgava: ZPR, 2015. (in Latvian)

[23] Ministry of Regional Development and Local Government of Latvia. Latvijas ilgtspējīgas attīstības stratēgija 2030.gadam (Latvian Sustainable Development Strategy 2030). Riga: PKC, 2010. (in Latvian)

[24] Ministry of Economics. Nacionālais Enerǵētikas un Klimata Plāns 2030 (Latvian Long - Term Strategy for Energy 2030). Riga: ME, 2020. (in Latvian)

[25] Pachemska T. A., Lapevski M., Timovski R. Analytical Hierarchical Process (AHP) method application in the process of selection and evaluation. Proceedings of the Gabrovo International Scientific Conference 'UNITECH' 2014:373380 .

[26] Krohling R. A., Pacheco A. G. C. A-TOPSIS - An approach based on TOPSIS for ranking evolutionary algorithms. Procedia Computer Science 2015:55:308-317. https://doi.org/10.1016/j.procs.2015.07.054

[27] Cabinet of Ministers. Ministru kaboneta noteikumi Nr. 628. Noteikumi par pašvaldību teritorijas attīstības plānošanas dokumentiem (Cabinet of Ministers Regulation No. 628. Regulations on Local Government Territorial Development Planning Documents). Latvijas Vēstnesis 2014:2015. (in Latvian)

[28] Pakere I., et al. Climate Index for District Heating System. Environmental and Climate Technologies 2020:24(1):406418. https://doi.org/10.2478/rtuect-2020-0024

[29] Ministry of Environmental Protection and Regional Development of the Republic of Latvia. Pašvaldības (Municipalities) [Online]. [Accessed 15.06.2021]. Available: https://www.varam.gov.lv/lv/pasvaldibas (in Latvian)

[30] Volkova A., Latõšov E., Lepiksaar K., Siirde A. Planning of district heating regions in Estonia. Int. J. Sustain. Energy Plan. Manag. 2020:27:5-16. https://doi.org/10.5278/ijsepm.3490.

[31] Volkova A., Latõšov E., Mašatin V., Siirde A. Development of a user-friendly mobile app for the national level promotion of the $4^{\text {th }}$ generation district heating. Int. J. Sustain. Energy Plan. Manag. 2019:20. https://doi.org/10.5278/ijsepm.2019.20.3. 